\title{
Employability of Graduates of Public and Private Management Education Institutes: A Case Study of Two Institutes in Sri Lanka
}

\author{
K. R. Ambepitiya* \\ Department of Management and Finance, General Sir John Kotelawala \\ Defence University
}

\begin{abstract}
The rationale for carrying out this research project lies in the findings of a survey regarding the mismatch between the qualifications and the demand for employment in the job market in Sri Lanka. This study aims to identify the degree of employability of graduates in the public and private sector higher education institutes which offer Management Degree programmes. A combination of quantitative and qualitative methods has been applied to elicit data. Primary data was collected through a questionnaire survey and interviews with 121 selected graduates who had graduated from two selected education institutes to extract views and experiences of graduates who use Facebook and those who use Google+ sites by applying the 'Snowball sampling' method of sampling. The findings suggest that both institutes have paid attention in developing employability skills in their students, supported developing enterprise skills and interpersonal skills which were seen inadequate to fulfil the requirements of the job market.
\end{abstract}

Keywords: Employability, public and private sector higher education, management stream.

\section{Introduction}

The demand of higher education has increased considerably and about 12,000 students go abroad each year to pursue higher education as a result of lack of placements in the state universities, (ICEF Monitor 2013). Although, approximately 300,000 students sit for the General Certificate of Examination (Advanced Level), only 27,600 received admissions in universities (UGC 2016). This is not a trend that favours the economic development of Sri Lanka because

*Correspondence should be addressed to Ms. K. R. Ambepitiya, Department of Management and Finance, General Sir John Kotelawala Defence University, Sri Lanka. (Email: kalpana.ambepitiya@gmail,com) 
this expenditure does not justify the benefits of educating students who go abroad (Nanayakkara 2010). Therefore, the government has invited the private sector to invest in education; about 100,000 seek further studies annually through the private sector education system and the state does not have the required funding to support this expansion (Dissanayake 2014). However, it is questionable whether these private institutes are adequately equipped to meet the expected quality standards of the country. Further, public universities are frequented with strikes, agitations, clashes and blood-shed and regular closing of faculties and campuses (Nanayakkara 2010) and these educational institutes are often criticized for not accommodating the volume and variety of students' demands, high unit costs arising from unproductive overheads, inflexible curricula and teaching methods, and the lack of research output (Vidanapathirana, 2000).

All the higher education providers in the private sector have established affiliations with different foreign universities and they follow their own quality assurance systems and standards. However, it is necessary to emphasise that there is no state body to supervise the private higher education institutes in Sri Lanka. Because of the necessity to fulfil the rapid demand for high quality higher education, both types of institutes are needed to upgrade the standards of creating employable graduates. Therefore, this study focuses on analysing the employability of graduates in public and private higher education institutes which offer Management Degree programmes.

\section{Research Problem}

The state universities in Sri Lanka are operated under the regulations of University Grants Commission (UGC). Therefore, these universities have to follow academic quality standards designed by the UGC and all academic work must be aligned to these standards. The private higher education institutes are affiliated universities of foreign countries. Therefore, these institutes basically follow the academic quality standards given by the mother universities. Many of these affiliated universities are from United Kingdom or Australia. Thus, the education provided by these universities can be different as a result of the quality and nature as maintained by the source university. It is surprising that there is no government authority to monitor the practises of private higher education in Sri Lanka. However, both sectors produce graduates and it is important to study the level of employability of these graduates as they come from two different environments. The study on the employability of both 
graduates might support both sectors to identify strengths and weaknesses of the education they provide.

\section{Methods}

The selection of the public and private institutes was based on convenience sampling by considering the availability of time and finance. The data was gathered through a survey conducted, based on the snowball sampling method where questionnaires were distributed using Facebook and google+ to graduates of selected institutes. Updated data bases were not available in these two institutes and it led to the selection of snowball sampling to collect participants. Further, online interviews were conducted via Skype to study employment transition, promotions and challenges after graduation. A total of 64 graduates from the public institute and 57 graduates from the private institute participated in this study. The response rate turned out to be 99\%. All graduates possessed business management degrees with specializations in finance, accounting, marketing and human resource management. All of them had passed out between 2008 and 2010. They possessed more than four years of working experience when the data was gathered. The questionnaire method was identified as a convenient method for data gathering. In order to identify qualitative factors related to the employability; the researcher conducted interviews with selected graduates. Employability has the influence of dependant variables such as updated theoretical knowledge, soft skills, job specific skills, technical skills and independent variables such as government actions and policies, income and social status, economic growth of the country, and employers' expectations and attitudes of graduates.

\section{Conceptual Framework}

The higher education involves factors such as academic knowledge, interpersonal skills development, and exposure to extracurricular activities, economic growth, labour efficiency, job demand, legal framework and political influences. Therefore, these factors can be categorized as dependant and independent factors according to their content and nature of influence. This is illustrated in Figure 01. Offers and services from universities can be dependant and external factors like the government decisions, economic growth, social level and employers' expectations are independent factors in university activities. The efficiency in higher education depends on all of these factors, along with the availability and utilization of finances. The economic growth can be expected to rise through the development of the higher education system of a country. At the same time, there is a positive connection between the skilled labour market and 
economic growth (Chandrasiri, 2008). Therefore, the aforementioned foundation must be strong in delivering and developing skills. However, to support the development of higher education in public and private sector requires identifying the common factors affecting the development of the university system. This will support the delivery of balanced mix of academic discipline and practical skills in both public and private sector higher education in Sri Lanka.

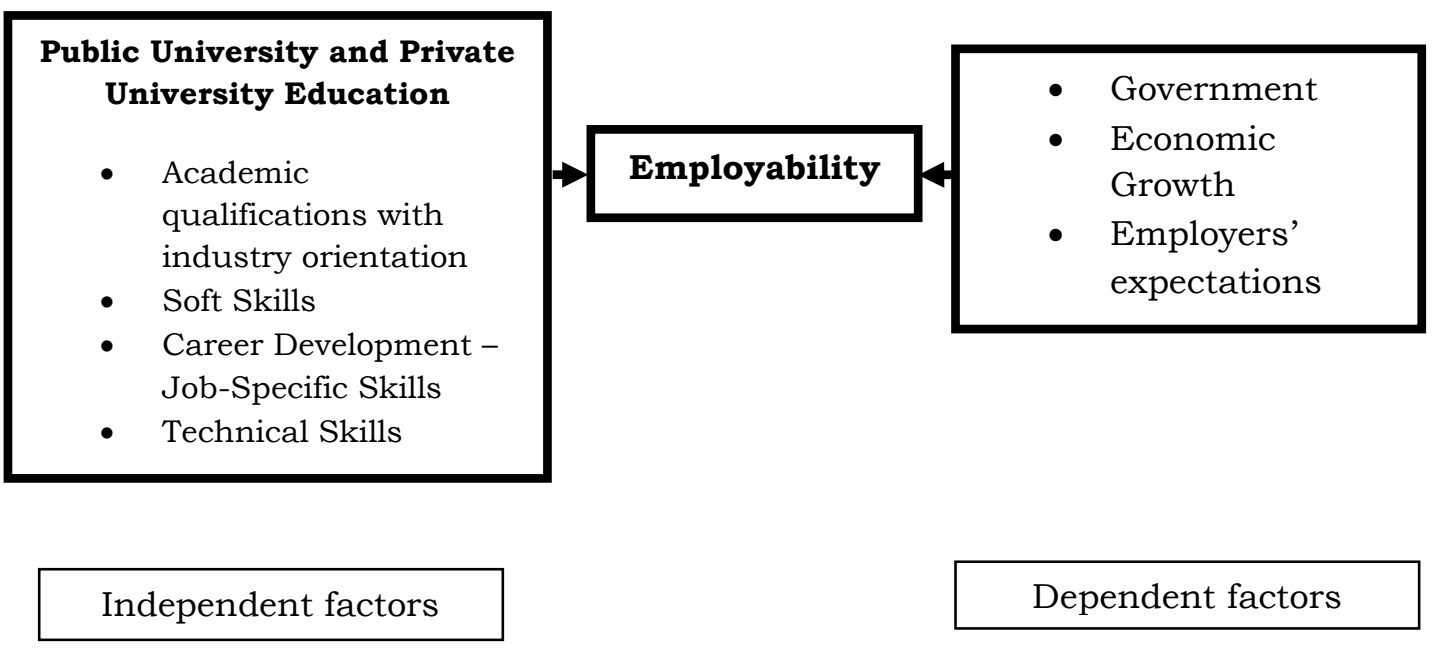

Figure 1. Conceptual Framework

\section{Literature review}

\section{Theoretical aspects of employability}

Many authors have described employability as the personal aptitude to carry out work. This definition mainly focused on the actual employability of people. Feyter et.al (2001) defined employability as "The number of tasks a worker can be assigned to or the amount of assistance needed in the job". Peck and Theodore (2000) provided a definition to the Employability as 'all individual factors that influence the future positioning in a given segment of the labour market'. Employability has economic and social consequences on macro- and micro level as the government is required to allocate a sufficient proposition of finance to education and creating employment. In this case, the demand would be created more towards white collar jobs and there will be less demand for blue collar jobs. This will develop a gap in the fulfilment of blue collar job markets. Thus, the authorities have a responsibility in balancing both sides on the development of employability. In this, education 
has a responsibility to supply and fulfil the requirements of employability.

Basically, employability is reflected on three theoretical perspectives, namely the Human Capital Theory, Actor Theory and Career Anchor Theory. The knowledge and skills are in great part of the product of investment and, combined with other human investments, predominantly account for the productive superiority of the technically advanced countries (Schultz, 1961). The actor theory implies that the individual and the collective actors are predetermined re-producers of the socially constructed environment. This approach presumes that neither economy as a driving force, institutional norm systems, nor political power structures, define the identity of the individuals, but these forces exert an important influence on the individuals' reflexive and subjective ways of creating their identity (Silverman, 1970). Eight themes in the career anchor such as functional competence, general managerial competence, independence, security, and entrepreneurial creativity, sense of service, pure challenge and lifestyle influence in an individual capability (Schein 1978). The human capital theory, actor theory and career anchor theory argue on education's change of an individual and its preparation of him/her with skills required for the job market. But social, economic and political conditions should provide the foundation in order to convert education into an investment. The Signalling theory argues that the investment in education requires the provision of sufficient return through employment.

\section{Importance of academic and practical knowledge in employability}

Education is a major measure of development of a country. Also it reflects the wealth and prosperity of a country. The main objective of university education is to produce graduates with soft and hard skills for different careers expecting them to be in the process of growth in the country. Universities facilitate the production of intellectual needs of a community as regards both academic knowledge and professional training (Ariyawansa, 2008). Higher levels of education becoming more important than lower levels of education, supports the notion that economic activities are becoming more knowledge intensive over time, so that the return to knowledge-based skills is rising (Aturupane, 2012). Employability focuses on a 'rational' approach as there is a range of factors that mediate employment such as, type of higher education institute, mode of study, student location and mobility, subject of study, previous work experience, age, ethnicity, gender and social class 
(Harvey, 2001). Employability can be defined as the propensity of students to obtain a job. However, most explicit and implicit definitions elaborate this core notion in diverse ways:

1. Job type: it implies getting a graduate-level job. They may be referred to as 'fulfilling work', or as a job that 'requires graduate skills and abilities' or as a 'career-oriented' job.

2. Timing: employability signaled by getting a job within a specified time after graduating. Attributes of recruitment: does employability signify an ability to demonstrate desired attributes at the point of recruitment?

3. Further learning: one view of employability holds that the degree is not the end of learning' and values graduates who are ready for further development, while in other places more weight on achievement at graduation, in addition to recognizing the importance of 'willingness to learn and continue learning'.

4. Employability skills: understood as the possession of basic 'core-skills', or an extended set of generic attributes, or attributes that a type of employer expects from an employee.(discipline-linked, sector-related, company-type) specifies (Flanders, 1995).

Effective employability is a collection of sufficient improvement in knowledge, the field of the subject, relevant experience and the development of positive attitudes and disciplines. These should be injected to individuals by the education institutes.

\section{Economic growth and employability}

The Higher education sector is in a position to supply more skilled labour and thereby promote economic growth (Chandrasiri, 2008). A Collaborative approach to higher education and an efficient labour market will lead a country to economic growth. In reality, it can be regarded as a high level or a specialised form of human capital contributes to the economic growth significantly. It is rightly regarded as the 'engine of development in the new world economy' (Castells 1994:15).

\section{Social aspects of employability}

Students entering a university may be immature in experience; they are exposed to a lot of freedom and independence without being prepared for the responsibility. This is coupled with a very brief orientation for only one week (sometimes, there is no orientation in private colleges) which in reality is missed by many; consequently, 
for many students it takes time to understand the system, especially those from rural schools who are coming to the city for the first time (Bunoti, 2011). The higher education environment should facilitate a proper orientation for students. In the meantime, they should pay attention to the preparation of their students for the demands of the future job market. Therefore, higher education institutes must work in collaboration with the respective industries.

\section{Role of higher education institutes}

People are unemployed because of the unemployment mismatch. And there are four main parties who are involved in this process namely, employers, candidates (graduates), state (government) and institutions (university). Most graduates do not have the required competencies, knowledge, skills and experience. Employers are the second party and in their view, graduates fail to fulfil requirements and core competencies. The third party is the educational institute and this system is criticized for not accommodating the volume and variety of students' demands, the high unit cost arising from unproductive overheads, inflexible curricula and teaching methods, and the lack of research output. The fourth party is the government which should also be involved in finding a solution to the problem (Vidanapathirana, 2000). The objectives of university education directly expect a "leading role from graduates" in different scales for the country's development. Therefore, for development, countries highly rely on their valuable human resources, particularly the essence of fresh intellectuals who are known as "university graduates". Hence, it can be argued that one of the universities' main obligations is to produce talented and competent graduates suitable for the development process of the country (Ariyawansa, 2008). Although there are a few established private higher education institutes, they are not labelled as 'universities' and there is little evidence that the education provided by them meets adequate standards.

\section{Employers' perspectives}

Employers reported that work related experience is an important consideration in recruitment (Weligamage \& Siengthai, 2003). Sri Lankan Universities have already taken action on this issue and most of the study programmes have included internship component into their curricula. This programme is running successfully and all stakeholders involved in this process are being benefitted. However, Sri Lanka further requires the development of programmes such as enterprise training, leadership development, career development and interpersonal skill development (Weligamage, 2009). The purpose of 
having career guidance services was to improve the links between universities and the industry, and thereby enhance the employability of university graduates (Chandrasiri, 2008).

One of the responsibilities of public and private higher education providers is to produce employable graduates with the intention of balancing the supply of the job market. Various definitions and approaches as discussed under employability of graduates focus on the development of enterprise skills with academic knowledge in relation to the demands of the job market. The required employable skills can vary and are categorized in different job segments. Developing the employment skills of a graduate is a vital need and is recognized all over the world. Therefore, the university system plays an important role in producing suitable and employable graduates to meet the requirements in the economy. There can be a system to update and upgrade degree programmes according to the trends in global higher education and the emerging requirements of the job markets. Universities are places of developing new theories and new knowledge through research and development. Therefore, universities must recognize emerging trends in employment and adjusting their degree programmes, accordingly.

\section{Results and Findings}

The analysis was based on empirical evidence which focuses on a total of 64 graduates from a public institute and 57 graduates from a private institute.

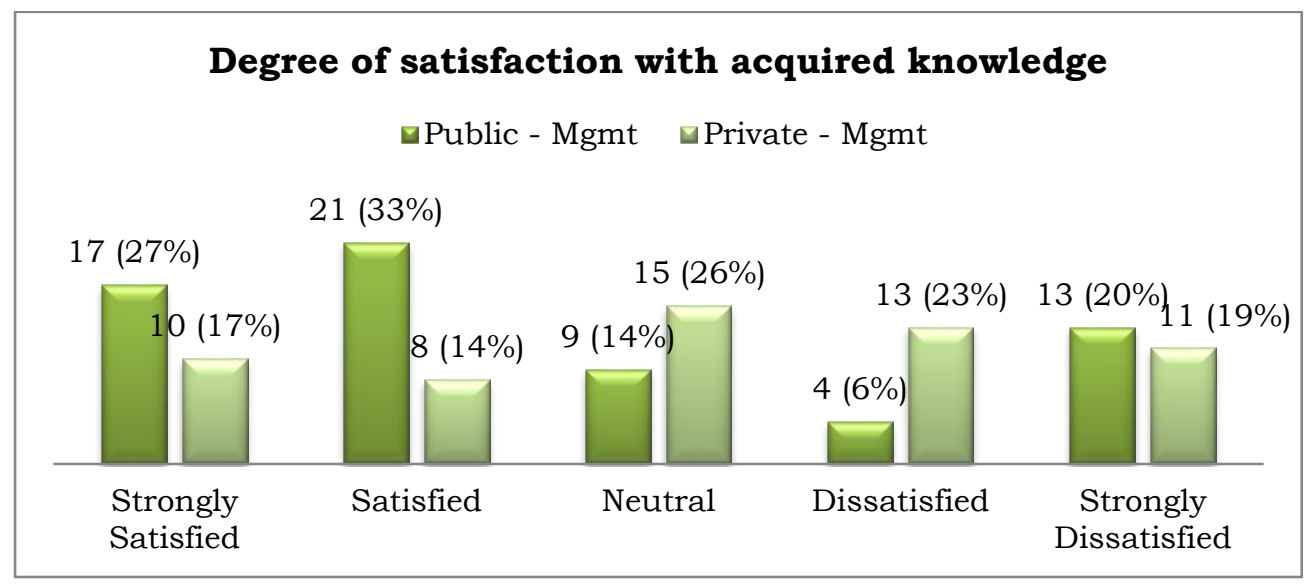

Figure 2. Data distribution showing degree of satisfaction with the acquired knowledge 
Majority of graduates stated that they were satisfied with the knowledge acquired from the public universities, while dissatisfaction has been shown by a relatively large part of graduates from the private institutes (Figure 2). In addition, $1 / 5^{\text {th }}$ of public university graduates were strongly dissatisfied with the inadequacy of knowledge imparted.

Table 1. Analysis on the theoretical knowledge provided by the university

\begin{tabular}{|c|c|c|c|c|c|c|c|c|}
\hline & \multicolumn{2}{|c|}{$\begin{array}{l}\text { Satisfaction with } \\
\text { the acquired } \\
\text { knowledge }\end{array}$} & \multicolumn{2}{|c|}{$\begin{array}{l}\text { Use of the } \\
\text { acquired } \\
\text { knowledge, in } \\
\text { employment }\end{array}$} & \multicolumn{2}{|c|}{$\begin{array}{l}\text { Satisfaction with } \\
\text { the gained } \\
\text { knowledge and job } \\
\text { specific skills }\end{array}$} & \multicolumn{2}{|c|}{$\begin{array}{l}\text { Employment } \\
\text { and its } \\
\text { relevance to } \\
\text { the degree }\end{array}$} \\
\hline & $\begin{array}{l}\text { Public } \\
\text { Mgmt }\end{array}$ & $\begin{array}{l}\begin{array}{l}\text { Private } \\
\text { Mgmt }\end{array} \\
\end{array}$ & $\begin{array}{l}\text { Public } \\
\text { Mgmt }\end{array}$ & $\begin{array}{l}\text { Private } \\
\text { Mgmt }\end{array}$ & $\begin{array}{l}\text { Public } \\
\text { Mgmt }\end{array}$ & $\begin{array}{l}\text { Private } \\
\text { Mgmt }\end{array}$ & $\begin{array}{l}\text { Public } \\
\text { Mgmt }\end{array}$ & $\begin{array}{l}\text { Private } \\
\text { Mgmt }\end{array}$ \\
\hline Mean & 12.8 & 11.4 & 32 & 28.5 & 12.8 & 11.4 & 32 & 28.5 \\
\hline $\begin{array}{c}\text { Standard } \\
\text { error }\end{array}$ & 2.9 & 1.2 & 14 & 2.5 & 2.4 & 3 & 19 & 13.5 \\
\hline Median & 13 & 11 & 32 & 28.5 & 13 & 10 & 32 & 28.5 \\
\hline Mode & Satisfied & Neutral & Yes & Yes & Neutral & Dissatisfied & Yes & Yes \\
\hline $\begin{array}{l}\text { Standard } \\
\text { deviation }\end{array}$ & 6.6 & 2.7 & 19.7 & 3.5 & 5.5 & 6.7 & 26.8 & 19 \\
\hline $\begin{array}{c}\text { Sample } \\
\text { variance }\end{array}$ & 44.2 & 7.3 & 392 & 12.5 & 30.7 & 45.3 & 722 & 365 \\
\hline Range & 17 & 7 & 28 & 5 & 14 & 17 & 38 & 27 \\
\hline
\end{tabular}

Most of the graduates were not satisfied with the job specific skills provided by the institutes (Table 1). Based on the mean value, over $50 \%$ of graduates from both institutes agreed that the acquired knowledge had supported them in securing employment (Table 1). Majority of graduates are employed in fields which are related to their degree specialization. This indicates that graduates have considered the specialized field in applying and selecting employments. 
Table 2. Data distribution of challenges faced in the first job

\begin{tabular}{|l|l|l|l|l|}
\hline \multirow{2}{*}{ Challenges faced in the first job } & \multicolumn{4}{|c|}{ Response } \\
\cline { 2 - 5 } & $\begin{array}{l}\text { Public - } \\
\text { Mgmt }\end{array}$ & \multicolumn{2}{l|}{ Mrivate - } \\
& 50 & $47 \%$ & 9 & $10 \%$ \\
\hline English Language & 12 & $11 \%$ & 10 & $12 \%$ \\
\hline Computer literacy & 11 & $10 \%$ & 23 & $27 \%$ \\
\hline Knowledge & 28 & $26 \%$ & 25 & $29 \%$ \\
\hline Practical skills & 5 & $5 \%$ & 16 & $19 \%$ \\
\hline $\begin{array}{l}\text { General knowledge application in the } \\
\text { job }\end{array}$ & 1 & 1 & 3 & $3 \%$ \\
\hline Any other & 107 & $\begin{array}{l}100 \\
\%\end{array}$ & 86 & $100 \%$ \\
\hline Total & & & & \\
\hline
\end{tabular}

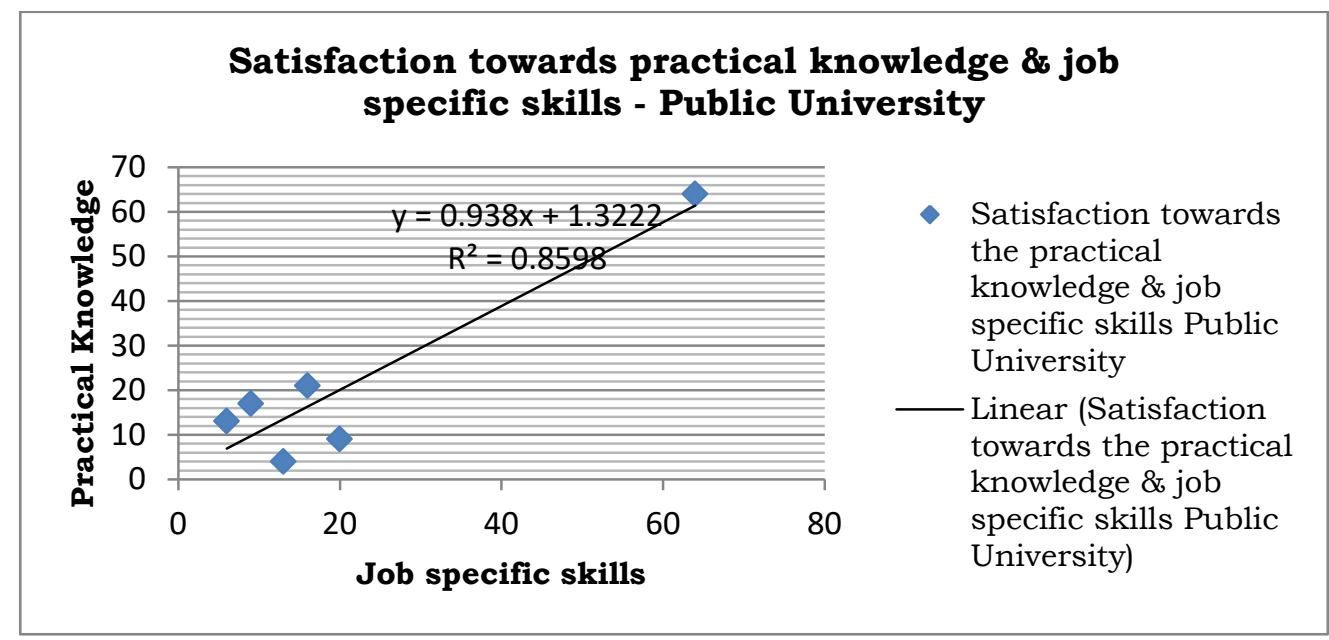

Figure 3. Satisfaction towards practical knowledge \& job specific skills - Public University: 64 participants

About $35 \%$ of public university graduates are employed in the public sector; public sector jobs are perceivably more secure than other jobs. They also provide higher benefits, such as a pension after retirement and require a lower work effort. Sometimes, they also carry more prestige (Rama, 2003). English Language fluency was the main challenge that graduates of the public university faced (Table 02). Graduates of private institutes mentioned that the institute had not provided enough opportunities to develop practical skills such as industrial training and internships. 
According to Figure 3, there is a positive correlation between the satisfactions of acquired knowledge and the practical skills provided by the Management Degree programme of the Public University. It could be said that satisfaction of acquired knowledge is positively caused by the increase in providing practical skills. Thus, it can be concluded that the impact of higher education must be present in both theoretical and practical knowledge development domains. In other words, these two variables are closely interrelated and an increase in one will make a considerable change in the other. Therefore, these two individual variables require equal attention in order to produce employable graduates.

According to Figure 4, there is a positive correlation between satisfaction gained from knowledge on practical skills provided by the Management Degree programme of the Private Institute. It could be said that satisfaction is positively caused by the extent of practical skills in private education. It can be identified that the satisfaction in both variables is caused by the increase in practical skills. As a result, it can be concluded that the private education considers developing the students' academic knowledge with the job specific skills. Therefore, these two individual variables require simultaneous development as well as equal attention in order to produce employable graduates.

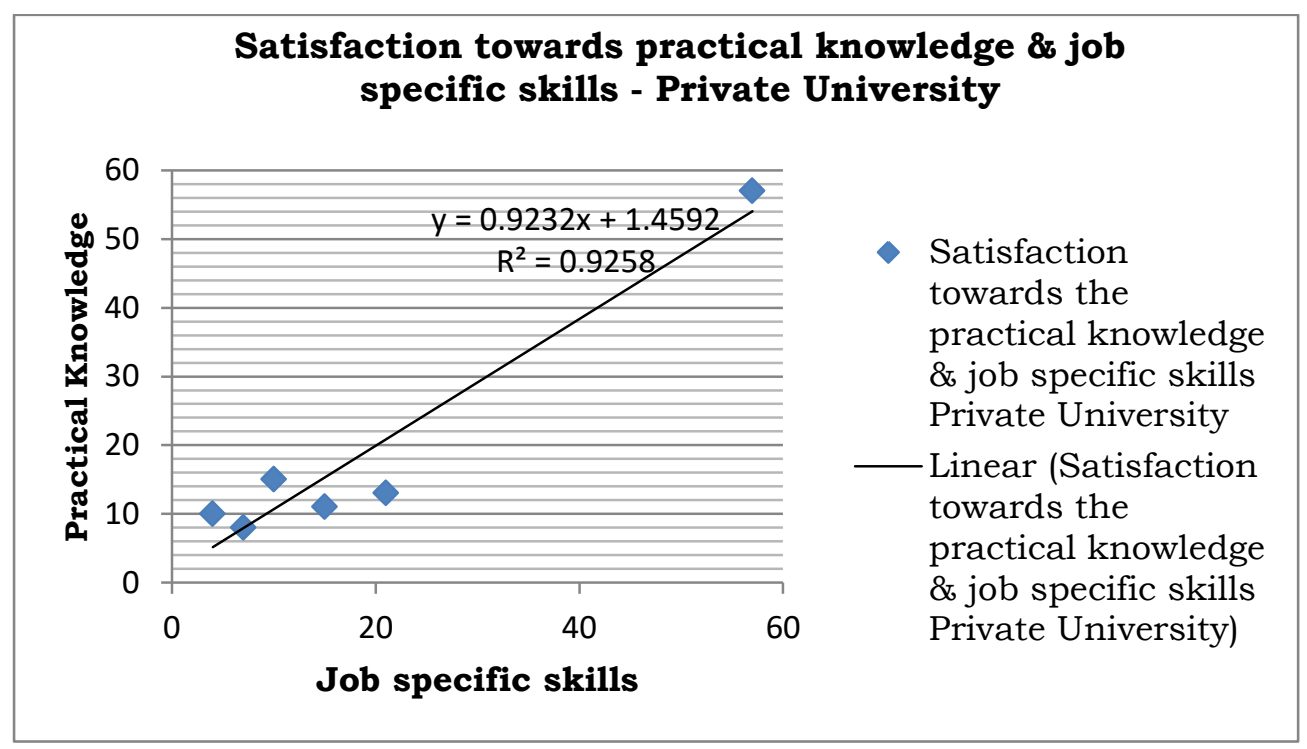

Figure 4. Satisfaction towards practical knowledge $\&$ job specific skills - Private University: 37 participants 


\section{Discussion}

\section{Employment by Discipline (\%)}

×Employed $\mathbf{x}$ Under employed $\quad$ Unemployed $\quad$ No Response

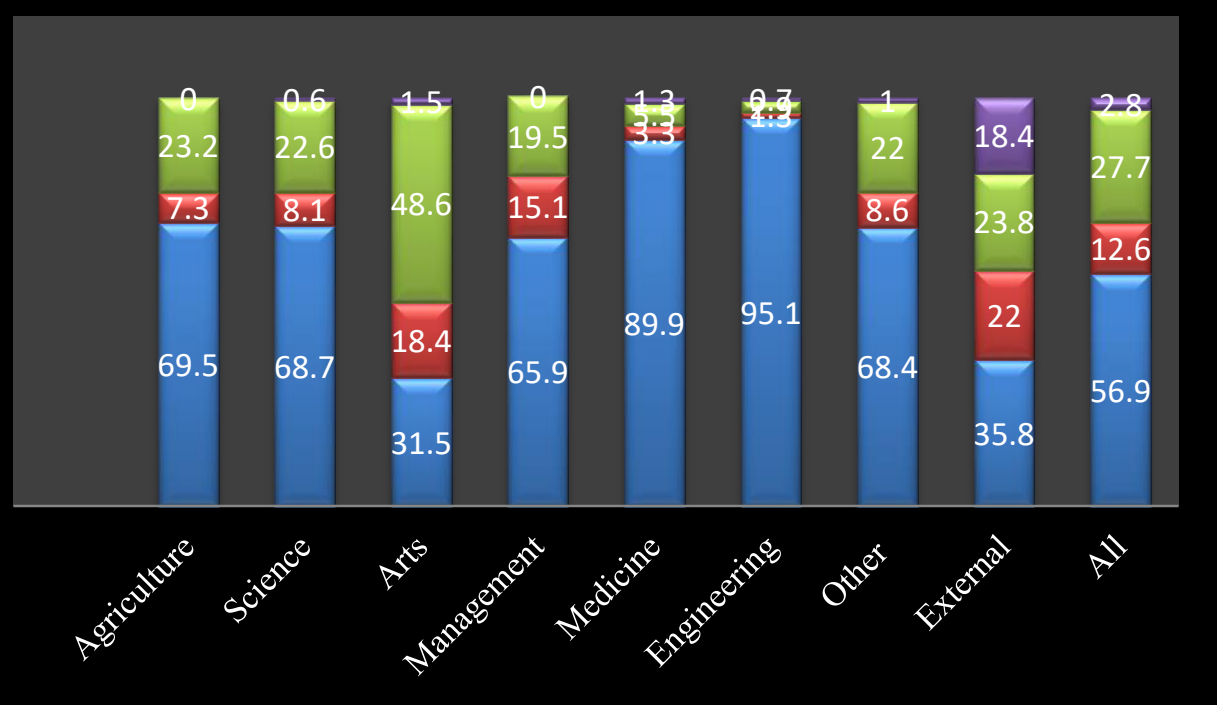

Figure 5. Employment by Discipline - Graduate Employment Ministry of Higher Education - 2012

The Ministry of Higher Education has been surveying the employability of graduates annually until 2013. This survey produces data on employability of recent graduates by the discipline and the university. Figure 5 shows the employability of graduates by the relevant discipline; management graduates have an employability rate of $66 \%$ in all the state universities. The data was collected on the day of convocation, which may be $6-12$ after the completion of their degrees. Therefore, it also reflects the waiting time to receive a job.

According to Table 3, there were 20 graduates who participated in the interview from the Public University and 12 of them were female graduates. Currently, 11 out of the 20 interviewees are working in public sector organizations, while 8 females worked in that sector. However, there were no graduates from the Private Institute who work for the public sector. There are 7 graduates who work in the private sector and a further 3 of them run their own companies. 
Table 3. Background of interviewees ( $\mathrm{M}=\mathrm{Male}, \mathrm{F}=\mathrm{Female})$

\begin{tabular}{|c|c|c|c|c|c|c|c|c|c|c|c|}
\hline & \multirow{3}{*}{$\begin{array}{l}\text { No of } \\
\text { gradu } \\
\text {-ates }\end{array}$} & \multirow{3}{*}{ M } & \multirow{3}{*}{$\mathrm{F}$} & \multicolumn{8}{|c|}{ Employment } \\
\hline & & & & \multicolumn{2}{|c|}{$\begin{array}{l}\text { Private } \\
\text { jobs }\end{array}$} & \multicolumn{2}{|c|}{$\begin{array}{l}\text { Public } \\
\text { jobs }\end{array}$} & \multicolumn{2}{|c|}{$\begin{array}{l}\text { Self } \\
\text { employed }\end{array}$} & \multicolumn{2}{|c|}{ Unemployed } \\
\hline & & & & $\mathrm{F}$ & $\mathrm{M}$ & $F$ & $\mathrm{M}$ & $\mathrm{F}$ & $\mathrm{M}$ & $\bar{F}$ & $\mathrm{M}$ \\
\hline $\begin{array}{l}\text { Public } \\
\text { Uni }\end{array}$ & 20 & 8 & 12 & 4 & 4 & 8 & 3 & - & 1 & - & - \\
\hline $\begin{array}{l}\text { Private } \\
\text { Uni }\end{array}$ & 10 & 5 & 5 & 4 & 3 & - & - & 1 & 2 & - & - \\
\hline Total & 30 & 13 & 17 & 15 & & 11 & & 4 & & - & \\
\hline
\end{tabular}

Table 4. Waiting time to get employment

\begin{tabular}{|l|l|l|l|l|l|}
\hline & $\begin{array}{l}\text { Internship } \\
\text { converted to } \\
\text { permanent } \\
\text { employment }\end{array}$ & $\begin{array}{l}\text { No } \\
\text { waiting }\end{array}$ & $\begin{array}{l}\text { One } \\
\text { month }\end{array}$ & $\begin{array}{l}\text { 02-03 } \\
\text { months }\end{array}$ & $\begin{array}{l}\text { 4-6 } \\
\text { months }\end{array}$ \\
\hline $\begin{array}{l}\text { Public } \\
\text { Uni }\end{array}$ & 9 & 5 & 2 & 3 & 1 \\
\hline $\begin{array}{l}\text { Private } \\
\text { Uni }\end{array}$ & - & 5 & 3 & 2 & - \\
\hline
\end{tabular}

Internship is compulsory in the curriculum of the Management stream in the Public University. Therefore, all graduates had gone through an internship programme. Some of them had converted the same internship to permanent employment after completing the required probation period (Table 4). Others received employment while they were on internship. One of the interviewees stated that she had to wait for three months after completing her studies to secure employment. Four interviewees out of the 30 are working for their own companies. The private university graduates were not required to stay long to receive jobs as they obtain jobs through personal contacts. 
Table 5. Data analysis on self-employment $(\mathbf{I}=$ Interviewee $)$

\begin{tabular}{|c|c|c|c|c|c|}
\hline $\begin{array}{l}\text { Graduate } \\
\text { proprietors }\end{array}$ & I & $\begin{array}{l}\text { Source of } \\
\text { investment }\end{array}$ & $\begin{array}{l}\text { Time taken } \\
\text { to start the } \\
\text { business }\end{array}$ & $\begin{array}{l}\text { The time } \\
\text { of joining }\end{array}$ & $\begin{array}{l}\text { Size of the } \\
\text { business }\end{array}$ \\
\hline $\begin{array}{l}\text { Public - } \\
\text { Mgmt Uni }\end{array}$ & A & Bank loan & $\begin{array}{l}\text { Expanded } \\
\text { the existing } \\
\text { business }\end{array}$ & $\begin{array}{l}\text { During } \\
\text { university } \\
\text { studies }\end{array}$ & $\begin{array}{l}\text { Medium } \\
\text { (business has } \\
\text { developed from } \\
\text { a micro level } \\
\text { to medium) }\end{array}$ \\
\hline \multirow[t]{3}{*}{$\begin{array}{l}\text { Private - } \\
\text { Mgmt } \\
\text { Uni }\end{array}$} & B & $\begin{array}{l}\text { Parents' } \\
\text { money }\end{array}$ & $\begin{array}{l}\text { Less than a } \\
\text { month }\end{array}$ & $\begin{array}{l}\text { After } \\
\text { completio } \\
\mathrm{n} \text { of the } \\
\text { degree }\end{array}$ & $\begin{array}{l}\text { Medium } \\
\text { (started as a } \\
\text { sister company } \\
\text { of the parents' } \\
\text { business) }\end{array}$ \\
\hline & C & $\begin{array}{l}\text { Parents' } \\
\text { money }\end{array}$ & $\begin{array}{l}\text { Expanded } \\
\text { the } \\
\text { parents' } \\
\text { business }\end{array}$ & $\begin{array}{l}\text { After } \\
\text { completio } \\
n \text { of the } \\
\text { degree }\end{array}$ & Small \\
\hline & $\mathrm{D}$ & $\begin{array}{l}\text { Parents' } \\
\text { money and } \\
\text { Bank loan }\end{array}$ & $\begin{array}{l}\text { Expanded } \\
\text { the } \\
\text { parents' } \\
\text { business }\end{array}$ & $\begin{array}{l}\text { After } \\
\text { completio } \\
\text { n of the } \\
\text { degree }\end{array}$ & $\begin{array}{l}\text { Medium } \\
\text { (started as a } \\
\text { sister company } \\
\text { of the parents' } \\
\text { business) }\end{array}$ \\
\hline
\end{tabular}

As Table 5 shows, three interviewees of the Private Institute have started their own businesses just after their graduation receiving investment from their parents/family members/only one interviewee of the Public University is running his own business which was financed through a bank loan. He had started this business as a micro enterprise and has now developed it to a small/medium scale enterprise.

\section{Incentives for Employment - Public sector and private sector companies}

The sample consists mainly of those who graduated in 2008 and had received a chance to get public sector jobs in the late 2009-2010 years. During the interview, it was found that there were incentives in both sectors which graduates looked for. 
Table 6. Ranking of incentives in working in the private/public sector

\begin{tabular}{|c|c|c|}
\hline Private Sector workers & Public Sector workers & \\
\hline $\begin{array}{l}\text { 1. Salary } \\
\text { 2. Quick Career } \\
\text { growth } \\
\text { 3. Accept } \\
\text { qualifications } \\
\text { 4. Relevance to the } \\
\text { field of study } \\
\text { 5. Family wellbeing } \\
\text { 6. Further } \\
\text { education } \\
\text { 7. Rewards } \\
\text { 8. Efficiency } \\
\text { 9. Exposure } \\
\text { 10. Culture } \\
\text { 11.Job security } \\
\text { 12. Transparent } \\
\text { recruiting } \\
\text { procedure } \\
\text { 13. Accept } \\
\text { experience } \\
\text { 14. Travel distance } \\
\text { 15. Freedom } \\
\text { 16. More holidays } \\
\text { and other } \\
\text { benefits } \\
\text { 17. Time saving } \\
\text { 18. Pension scheme }\end{array}$ & $\begin{array}{l}\text { 1. Job security } \\
\text { 2. Family wellbeing } \\
\text { 3. Pension scheme } \\
\text { 4. Travel distance } \\
\text { 5. Time saving } \\
\text { 6. Salary } \\
\text { 7. Freedom } \\
\text { 8. More holidays and } \\
\text { other benefits } \\
\text { 9. Further education } \\
\text { 10. Accept experience } \\
\text { 11. Rewards } \\
\text { 12. Quick Career } \\
\text { growth } \\
\text { 13. Accept } \\
\text { qualifications } \\
\text { 14. Relevant fields } \\
\text { available } \\
\text { 15. Efficiency } \\
\text { 16. Exposure } \\
\text { 17. Culture } \\
\text { 18. Transparent } \\
\text { recruiting } \\
\text { procedure }\end{array}$ & $\begin{array}{l}\text { Most } \\
\text { important }\end{array}$ \\
\hline
\end{tabular}

Table 6 presents the ranking order for each incentive and it is very clear that two different views have come out in these two types of sectors. Salaries, career growth, qualification requirement, relevance to the field of study and family wellbeing are the top most important incentives of private sector employees However, job security, pension, family wellbeing, travelling distance, time saving and freedom are the main concerns of public sector employees. One participant from the public university mentioned that he had to shift his employment from the private sector to the public sector as there are many benefits provided for public sector workers including the 
pension. It was also very easy to work close to home rather than be lodged in Colombo away from home.

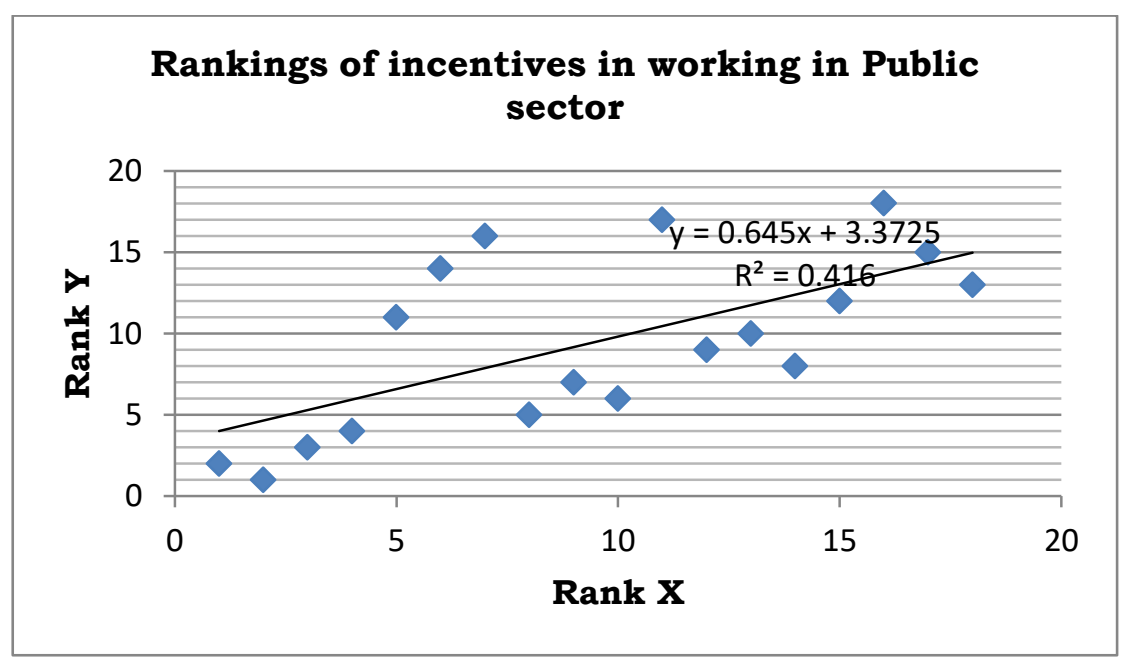

Figure 6. Spearman rank correlation of incentives in working in the public sector - Public University graduates

The Figure 6 presents the spearman's rank correlation of the preference of selecting public sector employment. This is a positive correlation based on the incentives listed in the Table 6. The graduates of the public university have more preference of selecting private sector employment.

The results of identifying the preference of working in the private sector are presented by the Figure 7 . This indicates a negative correlation with the ranked incentives presented in Table 6 . These graduates expect a high salary and quick career growth by working in the private sector. One of the participants from the public university said that although she was entitled to a government offer, she declined as she wanted to continue in the private sector considering the salary package and the relevance of the degree for further education. 


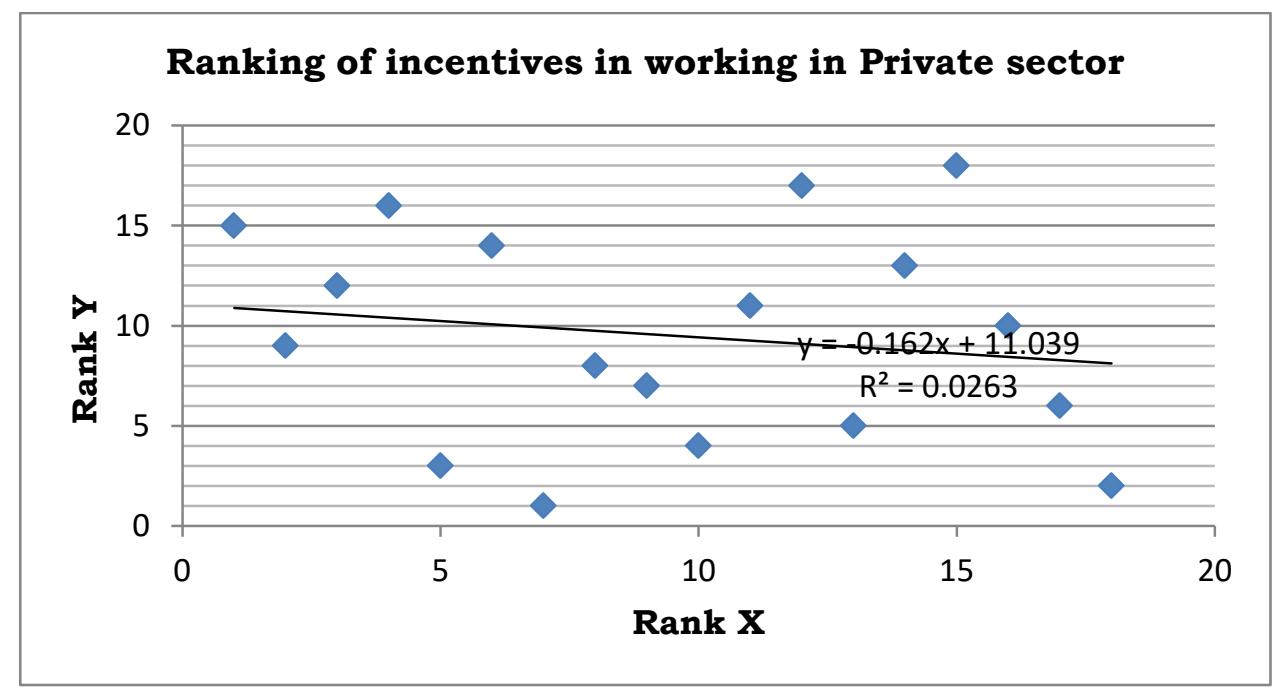

Figure 7. Spearman rank correlation of incentives in working in the private sector - Public University Graduates

While the majority of graduates stated their satisfaction of acquired knowledge from the Public University, dissatisfaction was stated by a greater number of graduates from the Private Institute. Most of the graduates were not satisfied with the practical and job specific skills provided by both institutes. Many graduates from both institutes, however, agreed that the acquired knowledge had supported them in their employment.

\section{Conclusion}

This study highlights the major factors affecting the employability of graduates of public and private higher education especially in the Management stream. Based on the results of this research relating to two institutes, it was observed that, academic knowledge, soft, practical and technical skill development are the major factors that prepare an undergraduate for future employment. These results also conclude that providing academic knowledge is not sufficient for effective employability of graduates. Findings have shown the dissatisfaction of graduates towards their academic programmes as inadequate in academic and practical skills development. It appears that higher education institutes must have a proper combination of academic knowledge and practical skills development which are expected by employers. As Weligamage and Siengthai mentioned in 2003, the Knowledge, skills, and talent will be crucial factors for growth in the future, while innovation and willingness to change will be driving forces in higher education. Therefore, these institutes have a major responsibility to improve their academic standards. 
Graduates are the future leaders of the country and they have to be ready with the modern changes in the industry. There should be a system set up for undergraduates to engage in industrial activities during their time of study and help create relationships and network with industries. Therefore, the nexus between university and corporate entities needs nourishing. The study shows that public university graduates prefer to work for public sector. However, this liking may be used to locate them in their home towns to develop those areas and facilitate them to strengthen opportunities for local businesses. The objectives of university education directly emphasize a "leading role from graduates" in different scales for the country's development (Ariyawansa, 2012). Public universities have to play changing preferences and interests of their students to work for private sector. The findings of this study may have significant influence on planning and strategising higher education in Sri Lanka; it will help both sectors to understand how they need to develop and upgrade themselves in order to produce employable graduates.

\section{Implications for Future Research}

This study provides an example where there is some convincing evidence to investigate further the requirement of developing higher education sector of Sri Lanka. The results show the factors affecting the employability of graduates in Management stream based on two private and public institutes. Further research may be justified to investigate the impact of applying these factors in developing the employability skills among both undergraduate programmes. This study highlights only the employability of management graduates; therefore, this can be expanded further to investigate the employability of other streams in higher education. The results of this study can enhance the development of academic standards in both public and private higher education institutes in Sri Lanka.

\section{References}

Ariyawansa, G. A. (2012). Employability of Graduates of Sri Lankan Universities. Sri Lankan Journal of Human Resource Management, 2 (1), pp. 91-104.

Aturupane, H. (2012). Economic Benefits and Options for FinancingHigher Education in Sri Lanka. Sri Lanka Journal of Advanced Social Studies, 2 (1), pp. 48-68.

Becker, G. S. (1964). Human Capital. National Bureau of Economic Research (NewYork). 
Brunner, K. and Meltzer, A. H. (1978). The Theory of Employment and Unemployment. Tepper School of Business, Paper 756. http://repository.cmu.edu/tepper (i.e. last accessed on 14/05/2014).

Castells, M. (1994). The university system: Engine of development in the new world economy. In: Salmi, J. \& Verspoor, A. (eds) Rivatilizing Higher Education. Oxford: Pergamon. pp. 14-40

Chandrasiri, S. (2008). The Labour Market Experience of University Graduates in Sri Lanka. Higher Education Policy, pp. 405423. https://doi.org/10.1057/palgrave.hep.8300164

Dissanayake, S, B. (2014). Equally important to promote private sectoreducation - SB 100,000 SL students going in for highereducation annually through private institutions. Lanka News Papers .com. Accessed 14 November 2014,http://www.lankanewspapers.com/news/2014/10/90 342.html.

Flamholtz, E. G. and Lacey. J. M. (1981). Personnel Management, Human Capital Theory, and Human Resource Accounting. (Barkley: University of California).

Feyter. De, Smulders. M. P. and Vroome. E. De, (2001). The employability of men and women. Features of influence', Journal for Labour Affairs, Vol. 17, No. 1, pp. 47-59.

Gunawardena, et. al. (1990). State of the art review on external efficiency of education in Sri Lanka, UNDP and Research Division, (Sri Lanka: National Institute of Education).

Harvey, L., 2001. 'Defining and measuring employability', Quality in Higher Education 7(2), pp. 97-110.ISSN 1353-8322.

ICEF Monitor 2013. Market Snapshot: Sri Lanka. Available from: http://monitor.icef.com/2013/10/market-snapshot-srilanka/. [10 October 2013].

Nanayakkara, G 2010. Reforming higher education for economic development. Sunday Observer Online. Accessed 14 November 2014, http://www.sundayobserver.1k/2010/11/07/fea02.asp

Peck, J. and Theodore, N. (2000) 'Beyond employability', Cambridge Journal of Economics, Vol. 24, No. 6, p.731. https://doi.org/10.1093/cje/24.6.729 
Rajapaksha, D. (2010). ESOFT - Paving the way to start your IT degree with just O/Ls. The Sunday Times, 2 May, Education Times. p.3.

Rama, M. (2003). The Sri Lankan Unemployment Problem Revisited; Review of Development Economics. Development Research group (Washington: The World Bank), 1(7), pp. 510-525.

Rao, D. B. (2003). Education, Employment and Human Resource Development (New Delhi: Discovery Publishing House).

Schein, E. H. (1978). Career Dynamics: Matching Individual and Organizational Needs (USA : Addison-Wesley).

Schultz, W. (1961). Investment in Human Capital. American Economic Association, The American Economic Review, 51(1), USA, pp. 1-17.

Simon, H. A. (1951). A Formal Theory of the Employment Relationship. Econometrica- The Econometric Society, 19 (3), pp. 293-305. https://doi.org/10.2307/1906815

Silverman, D. (1970). The Theory of Organizations (London: Heinemann).

Spence. M (1973). Job Market Signaling. The quarterly Journal of Economics-Harvard University, 87 (0355), pp. 374.

Staudinger, L. P. (2013). Education: Public or Private good, Politics and International Affairs Department, Philosophy in the Public Interests, Northern Arizona University, in: proceedings of the hot topics Café at The Museum of Northern Arizona, Northern Arizona, United States.

The World Bank. (2009). The Economic and Social Relevance of Higher Education: The towers of learning performance, Peril and promise of Higher Education in Sri Lanka. Human Development Unit, (Washington: The World Bank), pp. 69-70.

The World Bank. (2010). Sri Lanka, country summary of higher education: World Bank site resources, pp.10-16, http://siteresources.worldbank.org/EDUCATION/Resources/ 2782001121703274255/14392641193249163062/Sri Lanka CountrySummary.pdf. ( last accessed on 18/04/2013. 
University Grants Commission. (2016), Sri Lanka University Admissions (Colombo: Sri Lanka University Grants Commission), UGC.

Vidanapathirana, U. (2000). Employability and expectations of university students: A cross faculty comparison of the attributes of university students. Sri Lanka Association for the advancement of Science (SLAAS), in: Proceeding of the 56th Annual Session, Colombo, Sri Lanka, pp.281.

Vidanapathirana, U. (1997). The development of Science and Technology manpower in Sri Lanka. (Colombo: Asian Development Bank).

Weligamage, S and Siengthai, S. (2003) Employer Needs and Graduate Skills: The Gap between Employer Expectations and Job Expectations of Sri Lankan University Graduates, School of Management, in: Proceedings of the 9th International Conference on Sri Lanka Studies, (Bangkok: Thailand), pp. 917.

Weligamage, S. S. (2009). Graduates' Employability Skills: Evidence from Literature Review:- Enhancing Employability through Quality Assurance. ASAIHL 2009, University of Kelaniya, Sri Lanka .pp. 124.

Yorke, M. (2006). Employability in Higher Education: What It Is What It Is Not. Learning and Employability Series (United Kingdom: Learning and Teaching Support Network), pp.3-8.

York, K. M. (2009). Applied Human Resource Management - Strategic Issues and Experiential Exercises, (United Kingdom: Sage publication), pp. 1-405. 